\title{
Endocrine regulation of compensatory growth in fish
}

\section{Eugene T. Won and Russell J. Borski *}

Department of Biology, North Carolina State University, Raleigh, NC, USA

\section{Edited by:}

Yong Zhu, East Carolina University, USA

\section{Reviewed by:}

Weimin Zhang, Sun Yat-sen University, China

Wanshu Hong, Xiamen University, China

Takeshi Miura, South Ehime Fisheries Research Center, Japan

\section{*Correspondence:}

Russell J. Borski, Department of Biology, North Carolina State University, Box 7617, Raleigh, NC 27695, USA

e-mail: russell_borski@ncsu.edu
Compensatory growth (CG) is a period of accelerated growth that occurs following the alleviation of growth-stunting conditions during which an organism can make up for lost growth opportunity and potentially catch up in size with non-stunted cohorts. Fish show a particularly robust capacity for the response and have been the focus of numerous studies that demonstrate their ability to compensate for periods of fasting once food is made available again. CG is characterized by an elevated growth rate resulting from enhanced feed intake, mitogen production, and feed conversion efficiency. Because little is known about the underlying mechanisms that drive the response, this review describes the sequential endocrine adaptations that lead to CG; namely during the precedent catabolic phase (fasting) that taps endogenous energy reserves, and the following hyperanabolic phase (refeeding) when accelerated growth occurs. In order to elicit a CG response, endogenous energy reserves must first be moderately depleted, which alters endocrine profiles that enhance appetite and growth potential. During this catabolic phase, elevated ghrelin and growth hormone $(\mathrm{GH})$ production increase appetite and protein-sparing lipolysis, while insulin-like growth factors (IGFs) are suppressed, primarily due to hepatic GH resistance. During refeeding, temporal hyperphagia provides an influx of energy and metabolic substrates that are then allocated to somatic growth by resumed IGF signaling. Under the right conditions, refeeding results in hyperanabolism and a steepened growth trajectory relative to constantly fed controls. The response wanes as energy reserves are re-accumulated and homeostasis is restored. We ascribe possible roles for select appetite and growthregulatory hormones in the context of the prerequisite of these catabolic and hyperanabolic phases of the CG response in teleosts, with emphasis on GH, IGFs, cortisol, somatostatin, neuropeptide $Y$, ghrelin, and leptin.

Keywords: compensatory growth, fish, aquaculture, growth hormone, ghrelin, NPY, leptin, insulin-like growth factor

\section{INTRODUCTION: COMPENSATORY GROWTH OVERVIEW}

Compensatory growth (CG) is a period of accelerated somatic growth following the alleviation of growth-stunting conditions, that temporarily induces a steeper growth trajectory than that of cohorts not previously exposed to adverse conditions (Figure 1). This phenomenon was seminally documented nearly a century ago (Osborne and Mendel, 1916), and the term "CG" coined 40 years later (Bohman, 1955). CG has been documented in all vertebrate classes; humans (Prader et al., 1963; Boersma and Wit, 1997; Sapolsky, 1998), other mammals (Bohman, 1955; Wilson and Osbourn, 1960; Mersmann et al., 1987; Ryan, 1990), birds (Wilson and Osbourn, 1960), reptiles (Bjorndal et al., 2003; Radder et al., 2007), and amphibians (Alford and Harris, 1988; Vonesh and Bolker, 2005), but most extensively in fish (Ali et al., 2003 for review). Despite the diversity of animals and plants that can exhibit CG, the underlying mechanisms governing the response are still poorly understood.

A broad range of teleosts are capable of undergoing CG responses following alleviation of various growth-stunting conditions or their combination, including suboptimal temperature, crowding, or other stressful environments, and feed restriction, the latter reflecting the condition most often studied (Ali et al., 2003). A CG response has been reported in salmonids
(Dobson and Holmes, 1984; Jobling et al., 1993; Maclean and Metcalfe, 2001; Nikki et al., 2004), cyprinids (Russell and Wootton, 1992; Wieser et al., 1992), perciformes (Hayward et al., 1997; Picha et al., 2006, 2008b; Turano et al., 2007, 2008; Ferrando et al., 2009), flatfish (Cho, 2005; Heide et al., 2006), sticklebacks (Zhu et al., 2003), cichlids (Wang et al., 2000), catfish (Gaylord and Gatlin, 2000), and gadids (Jobling et al., 1994). While the degree of growth compensation achieved depends on species, it is nonetheless typically characterized by hyperphagia, improved feed conversion efficiency, and elevated specific growth rate (SGR). Although not often assessed, a critical feature of individuals undergoing CG is that their SGR is higher relative to similar-sized cohorts (i.e., SGR normalized to body mass) that were never subjected to stunting conditions (Skalski et al., 2005; Picha et al., 2006). Considering that CG results in enhanced growth rate and feed efficiency, it is not surprising that commercial production appears to be the driving impetus behind investigations into CG in fish, as the majority of studies to date involve cultivated species. Compared to conventional methods of fish farming that deploy a constant regimen, incorporation of rearing protocols that induce CG shows promise of reducing the amount of feed needed to grow at least some species of fish commercially. 


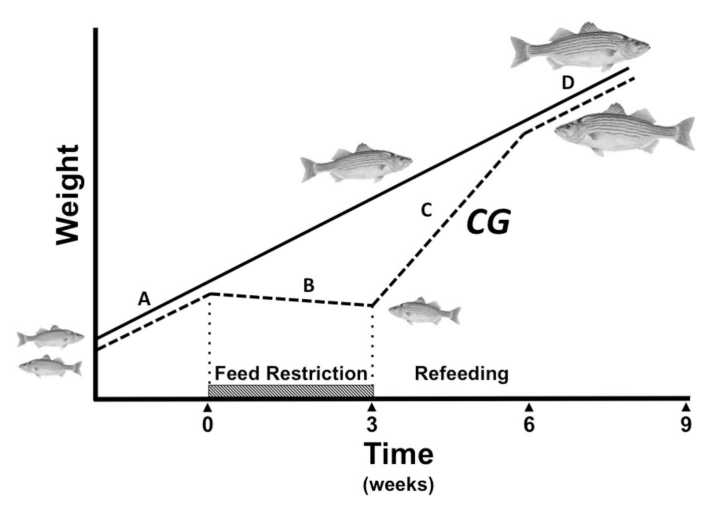

FIGURE 1 | Compensatory growth (CG) paradigm during fasting and refeeding (dashed line) compared to constant growth rate in fed controls (solid line). Normal growth (A) is disrupted by feed restriction (hatched bar), which results in a decline in the growth trajectory (B) and a size disparity compared to control animals fed a constant regimen. When feeding resumes, hyperphagia and enhanced growth axis activity drive a hyperanabolic phase (C) marked by a steeper growth curve than that of constantly fed animals. The CG response potentially allows stunted animals to fully compensate for lost growth opportunity and re-converge in size with constantly fed controls before the growth rate returns to normal (D)

Because most fish exhibit indeterminate growth and many are susceptible to seasonal changes in growth rate associated with natural variations in temperature and prey availability, they tend to exhibit a robust capacity for CG (Mommsen, 2001). Hence, they can ostensibly serve as valuable subjects for evaluating the metabolic and endocrine mechanisms that may contribute to anabolic processes generally, and hyperanabolism specifically. Acknowledging the diversity of fish in which CG has been documented and the complexity of the response itself, few attempts have been made to consolidate what is known about the endocrine mechanisms that underlie the response; however, the cumulative research on isolated components of CG provides insightful information from which to extrapolate a fundamental framework. In particular, the CG response can be divided into catabolic (e.g., during fasting, stress, low temperature) and anabolic (during realimentation or a return to more favorable conditions) phases, which elicit distinct and sequential endocrine responses (Figure 2; Table 1). The purpose of this review is to ascribe possible roles to select appetite and growth-regulatory hormones in the context of the catabolic and (hyper)anabolic phases of the CG response in teleosts, with emphasis on growth hormone $(\mathrm{GH})$, insulin-like growth factors (IGFs), cortisol, somatostatin, neuropeptide Y (NPY), ghrelin, and leptin.

\section{CATABOLIC STATE: PRIMING THE COMPENSATORY GROWTH RESPONSE}

In order to induce CG, a preceding catabolic period is necessary, the degree of which affects the overall magnitude of the response (Russell and Wootton, 1992; Wieser et al., 1992; Wang et al., 2000). This negative energy period depletes endogenous energy reserves and alters endocrine profiles that modulate appetite and growth potential once feeding is reinstated (Figure 2B). Brief periods of feed restriction do not sufficiently deplete stored energy or result
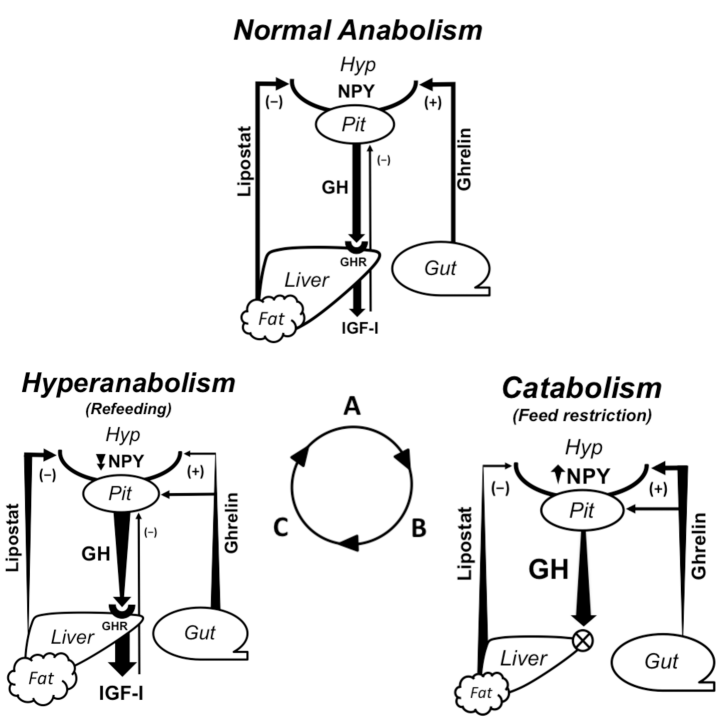

FIGURE 2 | Endocrine regulation of growth and appetite during normal anabolism, catabolism, and hyperanabolism (CG) resulting from feeding status. Growth is regulated by the GH/IGF axis; GH secreted into circulation by the pituitary binds its receptor (GHR) to stimulate hepatic IGF-I production, which systemically drives somatic growth and exerts negative feedback on $\mathrm{GH}$ secretion. Lipolysis is an alternate function of $\mathrm{GH}$ during catabolism. Peripheral signals from a lipostatic mechanism (anorexigenic), possibly leptin, and ghrelin (orexigenic) regulate energy intake by modulating NPY and other neuropeptides in the central feeding center. Ghrelin also functions as a GH secretagogue. Arrows show the direction of regulatory pathways; widening/narrowing of arrows represents a dynamic increase/decrease in a component over the duration of a particular metabolic state. (A) During regular feeding, energy homeostasis is maintained by matching energy intake and expenditure. Peripheral signals counter-regulate appetite centrally. Growth is regulated by nominal levels of circulating $\mathrm{GH}$, which stimulates IGF-I production via hepatic GHRs. (B) Fasting necessitates catabolic processes to provide energy for basal metabolism. Rising ghrelin production stimulates both appetite and circulating GH levels. Elevated lipolytic GH levels exploit stored energy reserves, decreasing lipostatic signaling. Reduced hepatic GHR expression desensitizes the liver to GH-induced IGF-I production. (C) Refeeding signifies the switch from catabolic to anabolic processes. Temporally elevated orexigens carried over from fasting drive hyperphagia. The return to positive energy status is characterized by the resumption of hepatic $\mathrm{GH}$ sensitivity and a steep rise in circulating IGF-I levels, which promotes accelerated growth. Eventually, the repletion of energy reserves and negative feedback from IGF-I returns GH and appetite to nominal levels, marking the return to normal growth rates. (PIT, pituitary; HYP, hypothalamus; NPY, neuropeptide Y; GH, growth hormone; GHR, growth hormone receptor; IGF-I, insulin-like growth factor I).

in stunting, and can be countered with behavioral compensation such as decreasing energy expenditure (Ali et al., 2003). Excessively long periods of fasting, on the other hand, lead to an irrecoverable lapse in growth that prevents full catch up to fed cohorts (Bilton and Robins, 1973; Gaylord and Gatlin, 2000). Nevertheless, moderate catabolism that taps expendable energy-storing tissues physiologically primes the CG response by opening pathways that elevate circulating GH and stimulate orexigens such as ghrelin and NPY. Studies in striped bass (Morone saxatilis) suggest that a prerequisite drop in the hepatosomatic index (HSI) to about 1.5 is 
Table 1 | Modulation of select endocrine factors during the transition from catabolism (fasting) to hyperanabolism (refeeding).

\begin{tabular}{|c|c|c|c|c|c|c|}
\hline & \multicolumn{3}{|c|}{ Catabolism (fasting) } & \multicolumn{3}{|c|}{ Hyperanabolism (refeeding) } \\
\hline & Response & Effect & Reference & Response & Effect & Reference \\
\hline GH & Elevated levels & $\begin{array}{l}\text { Lipolysis (protein } \\
\text { sparing) }\end{array}$ & $\begin{array}{l}\text { Sheridan (1986), Deng } \\
\text { et al. (2004), Albalat } \\
\text { et al. (2005), Small and } \\
\text { Peterson (2005), } \\
\text { Norbeck et al. (2007), } \\
\text { Picha et al. (2009) }\end{array}$ & $\begin{array}{l}\text { Residually high, } \\
\text { then decreasing }\end{array}$ & $\begin{array}{l}\text { Elevated IGF } \\
\text { production, } \\
\text { enhanced protein } \\
\text { uptake }\end{array}$ & $\begin{array}{l}\text { Collie and Stevens (1985), } \\
\text { Foster et al. (1991), Sun and } \\
\text { Farmanfarmaian (1992), Fine } \\
\text { et al. (1993), Norbeck et al. } \\
\text { (2007), Picha et al. (2009), } \\
\text { Pierce et al. (2011), Kling } \\
\text { et al. (2012) }\end{array}$ \\
\hline GHR (liver) & Downregulated & $\begin{array}{l}\text { Hepatic GH } \\
\text { resistance }\end{array}$ & $\begin{array}{l}\text { Gray et al. (1992), Mori } \\
\text { et al. (1992), Duan } \\
\text { (1998), Deng et al. } \\
\text { (2004), Saera-Vila et al. } \\
\text { (2005), Norbeck et al. } \\
\text { (2007), Picha et al. } \\
\text { (2008b) }\end{array}$ & Upregulated & $\begin{array}{l}\text { GH-induced IGF } \\
\text { production }\end{array}$ & $\begin{array}{l}\text { Gray et al. (1992), Small } \\
\text { et al. (2006), Picha et al. } \\
\text { (2008b) }\end{array}$ \\
\hline IGFs & Suppressed & Growth stasis & $\begin{array}{l}\text { Duan and Plisetskaya } \\
\text { (1993), Picha et al. } \\
\text { (2008b) }\end{array}$ & $\begin{array}{l}\text { Elevated/ } \\
\text { Overcompensated }\end{array}$ & $\begin{array}{l}\text { Enhanced somatic } \\
\text { growth }\end{array}$ & $\begin{array}{l}\text { Uchida et al. (2003), } \\
\text { Beckman et al. (2004), Picha } \\
\text { et al. (2008a); Picha et al. } \\
\text { (2008b) }\end{array}$ \\
\hline Ghrelin & Elevated levels & $\begin{array}{l}\text { Increased } \\
\text { appetite, GH } \\
\text { secretion }\end{array}$ & $\begin{array}{l}\text { Kaiya et al. (2003a); Ran } \\
\text { et al. (2004), Unniappan } \\
\text { and Peter (2004); Fox } \\
\text { et al. (2007), Picha et al. } \\
\text { (2009) }\end{array}$ & $\begin{array}{l}\text { Residually high, } \\
\text { then decreasing }\end{array}$ & Hyperphagia & $\begin{array}{l}\text { Riley et al. (2005), Matsuda } \\
\text { et al. (2006), Miura et al. } \\
\text { (2006) }\end{array}$ \\
\hline NPY & Elevated levels & $\begin{array}{l}\text { Increased } \\
\text { appetite }\end{array}$ & $\begin{array}{l}\text { Peng et al. (1994), } \\
\text { Silverstein et al. (1998), } \\
\text { Leonard et al. (2001) }\end{array}$ & $\begin{array}{l}\text { Residually high, } \\
\text { then decreasing }\end{array}$ & Hyperphagia & $\begin{array}{l}\text { Lopez-Patino et al. (1999), } \\
\text { Narnaware et al. (2000), } \\
\text { Volkoff and Peter (2001), } \\
\text { Aldegunde and Mancebo } \\
\text { (2006), Kiris et al. (2007) }\end{array}$ \\
\hline Leptin & $\begin{array}{l}\text { Species/tissue } \\
\text { dependent }\end{array}$ & $\begin{array}{l}\text { Regulation of } \\
\text { energy } \\
\text { metabolism? }\end{array}$ & $\begin{array}{l}\text { Kling et al. (2009), } \\
\text { Rønnestad et al. (2010), } \\
\text { Fuentes et al. (2012), } \\
\text { Frøiland et al. (2012), } \\
\text { Trombley et al. (2012), } \\
\text { Zhang et al. (2012) }\end{array}$ & $\begin{array}{l}\text { Species/tissue } \\
\text { dependent }\end{array}$ & Lipostatic signal? & $\begin{array}{l}\text { Johnson et al. (2000), } \\
\text { Nieminen et al. (2003), } \\
\text { Volkoff et al. (2003), } \\
\text { Murashita et al. (2008), } \\
\text { Gorissen et al. (2009), Won } \\
\text { et al. (2012) }\end{array}$ \\
\hline Cortisol & Elevated levels & $\begin{array}{l}\text { GH secretion, } \\
\text { hepatic GH } \\
\text { resistance, IGF-I } \\
\text { suppression }\end{array}$ & $\begin{array}{l}\text { Nishioka et al. (1985), } \\
\text { Kajimura et al. (2003), } \\
\text { Small and Peterson } \\
\text { (2005), Leung et al. } \\
\text { (2008), Pierce et al. } \\
\text { (2011) }\end{array}$ & Low levels & $\begin{array}{l}\text { Enhanced somatic } \\
\text { growth }\end{array}$ & $\begin{array}{l}\text { Kajimura et al. (2003), Leung } \\
\text { et al. (2008) }\end{array}$ \\
\hline Somatostatin & Elevated levels & $\begin{array}{l}\text { Hepatic GH } \\
\text { resistance, IGF-I } \\
\text { suppression }\end{array}$ & $\begin{array}{l}\text { Very and Sheridan } \\
\text { (2002), Sheridan and } \\
\text { Kittilson (2004) }\end{array}$ & Low levels & $\begin{array}{l}\text { Enhanced somatic } \\
\text { growth }\end{array}$ & Very and Sheridan (2002) \\
\hline
\end{tabular}

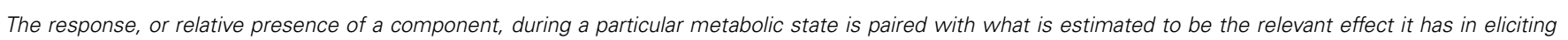
compensatory growth (GH, growth hormone; GHR, growth hormone receptor; IGFs, insulin-like growth factors; NPY, neuropeptide Y). 
necessary in order to elicit the response (Picha et al., 2006; Turano et al., 2007). The rise in appetite and alterations in physiology that occur during the catabolic phase preceding CG thereby potentiate hyperphagia and accelerated growth when feeding is reestablished. Hence, an adequate, but not excessive level of catabolism is essential to elevating the capacity of an animal to undergo CG and possibly achieve full catch-up growth when conditions improve.

\section{GROWTH HORMONE: FUNCTION AND REGULATION DURING CATABOLISM}

Under differential regulation by a host of neuroendocrine regulatory factors, GH serves dual roles depending on metabolic state, mobilizing lipids during catabolism and promoting somatic growth during anabolism (reviewed in Canosa et al., 2007). During fasting, rising plasma GH (MacKenzie et al., 1998), along with the related somatolactin in fish (Mingarro et al., 2002), protects non-expendable tissue such as muscle and vital organs from being catabolized by preferentially metabolizing fat over protein. This lipolytic function has been demonstrated in fish with exogenous $\mathrm{GH}$ treatment in vivo in coho salmon (Oncorhynchus kisutch; Sheridan, 1986) and in vitro in gilthead sea bream (Sparus aurata) adipocytes (Albalat et al., 2005), and is a critical adaptation to surviving negative energy periods.

Catabolically elevated GH secretion is mediated by reductions in metabolite levels (glucose/amino acids) and is stimulated in vitro and in vivo by orexigens, including ghrelin (Picha et al., 2009) and NPY (Peng et al., 1993), as well as by the lack of negative feedback inhibition from IGF-I. In striped bass pituitaries, IGF-I potently suppresses in vitro GH synthesis and release (Fruchtman et al., 2000; Picha et al., 2009), which likely contributes to elevated GH production during fasting when IGF-I levels are depressed. Cortisol, the dominant stress corticosteroid in fish (Mommsen et al., 1999; Dyer et al., 2004), also stimulates in vivo $\mathrm{GH}$ transcription in channel catfish (Ictalurus punctatus; Small and Peterson, 2005) and in vitro release from somatotrophs in Mozambique tilapia (Oreochromis mossambicus; Nishioka et al., 1985). Plasma GH levels are elevated by as much as twofold in rainbow trout (Oncorhynchus mykiss; Sumpter et al., 1991; Farbridge and Leatherland, 1992; Norbeck et al., 2007), Nile tilapia (Oreochromis niloticus; Toguyeni et al., 1996), channel catfish (Small and Peterson, 2005), and striped bass (Turano, 2007) during fasting when exogenous metabolic substrates are limited and fat reserves are needed for energy. Elevated $\mathrm{GH}$ is therefore able to mobilize lipids for maintenance of basal metabolism during food deprivation, but without directing limited energy resources toward growth due to catabolic $\mathrm{GH}$ resistance in the liver.

The actions of GH are mediated by GH receptors (GHRs), for which two distinct gene lineages exist in fish and which operate via different signaling pathways (Kittilson et al., 2011). The teleost GHR-1 is homologous to the single mammalian GHR (Fukamachi and Meyer, 2007) and has a shared affinity for both GH and somatolactin (Fukada et al., 2005) whereas the type 2 GHR is specific to GH activation (Fukada et al., 2004; Jiao et al., 2006; Pierce et al., 2007). The degree to which the individual receptor types mediate lipolysis or regulate growth is not known, but $\mathrm{GH}$ actions in various tissues are likely contingent on the differential expression of these receptors depending on whether catabolic or anabolic processes are required (de Celis et al., 2003; Saera-Vila et al., 2005; Very et al., 2005; Kittilson et al., 2011). During negative energy states, hepatic resistance to elevated plasma GH is evident as decreased IGF-I production (Duan and Plisetskaya, 1993; Picha et al., 2008b) due to catabolic suppression of ligand binding to GHRs (Gray et al., 1992; Mori et al., 1992; Duan, 1998). This type of hepatic GH resistance during catabolism is characterized as downregulated GHR mRNA levels in striped bass (Picha et al., 2008b) and gilthead seabream (Saera-Vila et al., 2005), decreased hepatic GH binding in gilthead sea bream (Pérez-Sánchez et al., 1994) and both reduced hepatic GHR transcript and GH-binding in rainbow trout (Norbeck et al., 2007) and black seabream (Acanthopagrus schlegeli; Deng et al., 2004); alleviated in all cases by refeeding.

Hepatic GH resistance is likely mediated, in part, by cortisol and somatostatins during fasting. While stimulating GH synthesis, cortisol simultaneously suppresses hepatic IGF-I production through direct downregulation of transcription and synthesis in silver sea bream (Sparus sarba; Leung et al., 2008) and Mozambique tilapia (Kajimura et al., 2003; Pierce et al., 2011), or in conjunction with suppression of GHR transcript in channel catfish (Small et al., 2006). Somatostatins also reduce GH binding in the liver and suppress IGF-I gene expression (Very and Sheridan, 2002; Sheridan and Kittilson, 2004). Hepatic resistance to GH through reduced receptor expression and signaling, despite elevated levels of circulating ligand, signifies an uncoupling of the lipolytic and growth-regulatory functions of GH during negative energy states. The carry over of catabolically elevated GH, in turn, helps drive enhanced IGF-I production and may ultimately potentiate hyperanabolic growth pending the return to a positive energy state when hepatic GHR signaling resumes.

\section{GHRELIN: PERIPHERAL MODULATOR OF GH SECRETION AND APPETITE DURING CATABOLISM}

The rise in lipolytic GH during fasting is fundamentally imperative for sparing muscle and organs by deferring catabolism to fat stores. Upstream regulation of enhanced GH production during fasting is therefore dependent on an indicator of nutritional state to coordinate catabolic lipolysis with negative energy states. The orexigenic peptide, ghrelin, responds to fasting and is a potent $\mathrm{GH}$ secretogogue, comparable in effect to growth hormone releasing hormone (GHRH) (Hataya et al., 2001). The differential regulation of appetite and GH secretion by ghrelin in fish relies on specific Ser3 modifications (Unniappan et al., 2002; Riley et al., 2005; Jönsson et al., 2007). Ghrelin's actions are mediated by the growth hormone secretogogue receptor (GHSR), which is distinct from the GHRH receptor (Kojima et al., 1999). In fish, ghrelin mRNA is expressed predominantly in the gut and stomach (Unniappan and Peter, 2005), and it is interestingly the only known peripheral orexigen originating from the gut considering its proximity to nutrient uptake. To a lesser extent, central ghrelin gene expression has also been detected in rainbow trout (Kaiya et al., 2003a), eel (Anguilla japonica; Kaiya et al., 2003b), Mozambique tilapia (Kaiya et al., 2003c), and goldfish (Carassius auratus; Unniappan et al., 2002), as has GHSR transcript in black sea bream (Chan and Cheng, 2004). Ghrelin stimulates GH secretion in vitro in cultured orange spotted grouper (Epinephelus coioides) pituitaries (Ran et al., 2004) and in vivo and in vitro in Mozambique tilapia (Fox et al., 2007), 
rainbow trout (Kaiya et al., 2003a), goldfish (Unniappan and Peter, 2004), and striped bass (Picha et al., 2009). Besides actively stimulating GH secretion, in mammals ghrelin also independently acts as a functional antagonist to somatostatin (Arvat et al., 2001; Tannenbaum and Bowers, 2001; Tannenbaum et al., 2003), itself an inhibitor of GH secretion. Ghrelin is therefore capable of peripherally stimulating GH secretion through vagal afferents originating near the stomach, as well as by acting directly on the pituitary or through modulation of central GH release factors.

Ghrelin is also a potent appetite stimulant, serving as a peripheral signal to the brain during periods of negative energy balance (Banks et al., 2002; Cummings et al., 2004). Orexigenic ghrelin signaling operates via vagal afferents as well as central pathways paralleling those of $\mathrm{GH}$ regulation, although appetite and $\mathrm{GH}$ stimulatory pathways are independent (Tschop et al., 2000; Wren et al., 2000; Nakazato et al., 2001; Date et al., 2002). The orexigenic properties of ghrelin have been reviewed in mammals (Anderson et al., 2005; Ueno et al., 2005) and fish (Unniappan and Peter, 2005; Kaiya et al., 2008). Appetite was stimulated by a single IP/ICV injection of homologous ghrelin in goldfish (Matsuda et al., 2006; Miura et al., 2006) and by chronic treatment in tilapia (Riley et al., 2005). The effect of ghrelin on appetite is less clear in salmonids, which undergo seasonal alterations in feeding behavior (Metcalfe et al., 1986; Metcalfe and Thorpe, 1992). In juvenile rainbow trout, IP injection of rat ghrelin was orexigenic (Shepherd et al., 2007) as in other fish, although both IP and ICV delivery of native ghrelin suppressed feeding (Jönsson et al., 2010) in similar-sized trout or had no effect (Jönsson et al., 2007) when injected IP in larger fish. These variable results suggest that ghrelin may have different functions depending on life stage in salmonids, and that homologous and heterologous peptides could account for the different effects observed in these studies. Future research will need to consider these contingencies.

In accord with its orexigenic function, ghrelin levels tend to rise during fasting and decline after feeding in mammals (Ueno et al., 2005) as well as in fish (Unniappan et al., 2004; Canosa et al., 2005; Matsuda et al., 2006; Terova et al., 2008; Picha et al., 2009). Exceptions were observed in tilapia (Riley et al., 2008) and rainbow trout (Jönsson et al., 2007), however, and may represent species-specific differences in regulation of the ghrelin system among teleosts. Ghrelin nonetheless appears to be an important peripheral signal for regulating both GH secretion and appetite based on nutritional status. Studies further suggest that stimulation of ghrelin production during fasting and the lag time between refeeding and the return of ghrelin to basal levels may depend on the degree to which catabolic processes deplete energy reserves. In the short term, gut and hypothalamic preproghrelin mRNA along with circulating ghrelin levels increased on the order of days in fasted goldfish, then went down within several hours after refeeding (Unniappan et al., 2004). European seabass (Dicentrarchus labrax) stomach ghrelin mRNA levels increased over 35 days of fasting, then dropped back to basal levels after 10 days of refeeding (Terova et al., 2008). Striped bass exhibited elevated plasma ghrelin levels after 3 weeks of fasting and a 43-fold increase relative to fed controls after continued fasting and cold-banking for 90 days, followed by a return to baseline within 21 days of refeeding and temperature warm up (Picha et al.,
2009). Plasma ghrelin and GH levels in the treatment fish of this trial were concordantly elevated during fasting and then eventually returned to control levels after refeeding. Refeeding was additionally marked by hyperphagia and full catch up growth. Picha et al. (2009) show that in vitro stimulation of GH by ghrelin occurs in somatotrophs derived from both continually fed and fasted fish, but not from refed fish, suggesting the hypophyseal GHSR may be downregulated during CG, which would contribute to the eventual decline in $\mathrm{GH}$ seen during refeeding of fasted fish. Taken together, the trends in ghrelin regulation and function observed in fish suggest that catabolically elevated ghrelin simultaneously raises lipolytic plasma GH while priming a hyperphagic response during refeeding. The coincidence of these effects likely contributes significantly to the CG response, and may in part explain why a catabolic phase is needed to precede hyperanabolism.

\section{CENTRAL MODULATORS OF APPETITE}

Appetite is increased during fasting through the upregulation of central orexigenic neuropeptides (Kalra et al., 1999), with similar hormones existing in mammals and fish. In the latter, a number of orexigens are expressed in the pre-optic hypothalamic region (Volkoff et al., 2005), which appears to be the teleost ana$\log$ to the mammalian feeding center. Central injection of NPY (Lopez-Patino et al., 1999; Narnaware et al., 2000; Aldegunde and Mancebo, 2006; Kiris et al., 2007), galanin (de Pedro et al., 1995; Volkoff and Peter, 2001), and orexins (Volkoff et al., 1999) stimulate appetite in teleosts. While NPY is considered the most potent orexigen in fish and has garnered the most research, these other central peptides interact with NPY to augment appetite in response to negative energy status (Volkoff et al., 2005).

Central NPY (Peng et al., 1994; Silverstein et al., 1998; Leonard et al., 2001) and AgRP (Cerdá-Reverter and Peter, 2003) mRNA is regulated by nutritional state and increases during negative energy states to promote energy intake. Ghrelin stimulates central gene expression of NPY, which has been shown to mediate the orexigenic effects of ghrelin in goldfish (Miura et al., 2006). As in mammals (Stephens et al., 1995; Schwartz et al., 2000), the anorexigen, leptin, suppresses the effects of exogenous NPY on appetite in fish (Lin et al., 2000; Volkoff et al., 2003). In rodents, appetite is stimulated by NPY when ghrelin levels are high and leptin low (Bagnasco et al., 2002), or during periods of negative energy balance; however, leptin's regulation by metabolic state in fish is equivocal (discussed below). The upregulation and interaction of central orexigenic neuropeptides during fasting likely culminates in the hyperphagic response during refeeding, thus providing the substrate and energy necessary for a CG response to occur.

\section{REFEEDING: HYPERPHAGIA AND HYPERANABOLISIM (COMPENSATORY GROWTH)}

Hyperanabolism, or the accelerated growth phase that characterizes CG, is the result of hyperphagia and heightened growth axis activity during refeeding, particularly in the rapid rise in IGF-I production that occurs when hepatic sensitivity to GH returns. As discussed in the first half of this review, CG is preceded by a catabolic phase that primes an organism for hyperanabolism. If the endurance of the catabolic state is sufficient, 
and food is ample when feeding resumes, then a temporal hyperphagic response is elicited and a net positive energy state achieved through the reintroduction of exogenous energy and metabolic substrates. When energy stores are regained, orexigenic signaling declines and hyperphagia subsides. Under these terms, an organism exhibits lipostatic regulation of energy homeostasis (Jobling and Johansen, 1999), a system in which energy reserves are maintained within a certain range by endocrine signals derived from energy-storing tissues that regulate feeding and energy expenditure. CG seems to occur during the lag time between refeeding and the lipostatic abatement of hyperphagia and enhanced growth axis activity.

\section{HYPERPHAGIA AND ASSIMILATION EFFICIENCY}

Hyperphagia is an integral component of CG (Ali et al., 2003) and is a common response to energy deficit in a variety of fish; European minnow (Phoxinus phoxinus; Russell and Wootton, 1992), Atlantic salmon (Salmo salar; Bull and Metcalfe, 1997), centrarchid sunfish (genus Lepomis; Hayward et al., 1997), Nile tilapia (Wang et al., 2000), striped bass (Picha et al., 2008b; Turano et al., 2008), and stickleback (Gasterosteus aculeatus; Zhu et al., 2003). The magnitude of the hyperphagic response depends on the duration of fasting in salmon, and appears to be largely influenced by the degree to which lipid reserves are depleted by catabolic processes (Bull et al., 1996). Hyperphagia during CG is attributable to catabolically elevated levels of orexigens that are upregulated during negative energy states.

Hyperanabolism during refeeding is fueled by an influx of metabolic substrates that are rapidly allocated to somatic growth through heightened mitogenic activity of the growth axis; however, hyperphagia alone may not account for the accelerated growth rate experienced during CG. Gurney et al. (2003) propose, through energetics modeling, that high substrate assimilation rates during hyperphagia drive CG by partitioning resources specifically to skeletal growth rather than to energy reserve deposition. Skalski et al. (2005) elaborate on the energetics model of hyperanabolism, suggesting that physiological changes, including increased assimilation efficiency during feeding and reduced mass-specific maintenance costs during fasting, work in conjunction with hyperphagia to drive CG in striped bass. A subsequent study that normalizes SGR to body size supports that the growth rate is significantly higher in fasted/refed hybrid striped bass relative to controls (Picha et al., 2008b), and is not merely an allometric artifact of smaller, stunted fish compared to larger, fed cohorts.

The mechanism that adjusts energy allocation around assimilation rate is undefined, although the lipolytic and growth promoting functions of $\mathrm{GH}$, along with its regulatory profile under variable metabolic conditions, suggests an influential role in optimizing substrate conversion to skeletal growth. Long-term $\mathrm{GH}$ treatment in rainbow trout improved feed conversion by $60 \%$ (Kling et al., 2012). Exogenous GH treatment enhanced amino acid uptake (Collie and Stevens, 1985) as well as growth rate, appetite, and food conversion in coho salmon (Markert et al., 1977). In fed striped bass, weekly bovine GH injection increased the number of intestinal amino acid transporters and intestinal mass (Sun and Farmanfarmaian, 1992), suggesting improved protein uptake capacity. Similarly in carp (Cyprinus carpio; Fine et al., 1993) and rainbow trout (Foster et al., 1991), protein assimilation, and feed conversion were improved by chronic GH treatment. The carry over of catabolically elevated GH after refeeding, in addition to driving somatic growth through stimulation of IGFs, may also improve protein assimilation at a time when substrates are in abundance due to elevated feeding (Peter and Marchant, 1995; MacKenzie et al., 1998).

\section{HYPERANABOLISM: AUGMENTATION OF THE GH/IGF GROWTH AXIS}

Compensatory growth ultimately refers to the rapid growth, or hyperanabolic, response that occurs during the feeding of previously fasted animals, and which allows them to recover lost growth opportunity. During positive energy states, circulating GH binds hepatic GHRs to induce production and secretion of IGF-I, the prominent mitogen responsible for somatic growth in vertebrates (Froesch et al., 1985; Picha et al., 2008a). Like IGF-I, hepatic IGFII transcription is also stimulated by $\mathrm{GH}$ in a broad range of fish (Shamblott et al., 1995; Duguay et al., 1996; Carnevali et al., 2005; Gabillard et al., 2006; Moriyama et al., 2008a,b; Pierce et al., 2011) and remains responsive to $\mathrm{GH}$ into adulthood. Hepatic GHR transcription positively correlates with GH binding in gilthead sea bream (Pérez-Sánchez et al., 1994) and with circulating IGF-I levels in channel catfish (Small et al., 2006) during fasting and refeeding, corroborating that metabolic state mediates $\mathrm{GH}$ signaling through changes in GHR expression in the liver where the majority of endocrine IGFs are produced (Reinecke and Collet, 1998; Vong et al., 2003; Terova et al., 2007). Chronic GH treatment increases growth rate in a diverse range of fish (Markert et al., 1977; Weatherley and Gill, 1987; Agellon et al., 1988; Cavari et al., 1993), suggesting that the catabolically elevated GH levels that temporarily persist during refeeding may contribute to an accelerated growth rate by stimulating the growth axis. The return of hepatic sensitivity to $\mathrm{GH}$ during refeeding, which reinstates IGF synthesis, is therefore critical to CG. The duration of high plasma GH levels may depend on catabolic history and the extent to which energy reserves are depleted during fasting, but appears to decline back to normal levels within 2 weeks of refeeding in rainbow trout and striped bass (Norbeck et al., 2007; Picha et al., 2009).

Consistent with the mitogenic attributes of IGFs, plasma IGFI (Uchida et al., 2003; Beckman et al., 2004) and hepatic IGF-I and II mRNA (Picha et al., 2008b) levels positively correlate with SGR in fasted and refed fish. The relative change in circulating IGF-I over a growth increment is an even better corollary to SGR in striped bass than absolute IGF-I levels (Picha et al., 2006), which may indicate enhancement of IGF receptor sensitivity during the transition from catabolic back into anabolic states as plasma IGF-I levels are in the process of rising. The steep rebound of depressed plasma IGF-I levels during the refeeding of fasted striped bass corresponded directly to the hyperanabolic phase of the growth curve (Picha et al., 2008b). Moreover, transcript levels of hepatic GHRs and IGFs in these fish during refeeding actually exceeded those of constantly fed control fish, suggesting that overcompensation in expression of key growth-regulatory hormones may be contributing significantly to the accelerated growth that occurs with CG (Picha et al., 2008b). This overcompensation is 
further exacerbated in striped bass when the alleviation of a previous period of feed restriction is combined with cold-banking, similar to what wild fish experience during spring warm up when temperature and prey availability are more optimal for growth (Perez-Sanchez and Le Bail, 1999; Mingarro et al., 2002; Picha et al., 2009). Similarly, overcompensation in circulating IGF-I concomitant with enhanced activation of IGF-I signaling in muscle tissue was observed in fine flounder (Paralichthys adspersus; Fuentes et al., 2011). An elevation in muscle IGF-I mRNA levels has been observed in a number of other fish (Chauvigne, 2003; Montserrat et al., 2007a,b; Picha et al., 2008b; Kling et al., 2012), suggesting a parallel autocrine or paracrine mechanism within the skeletal tissue itself. Taken together, the coordinated dynamics of the GH/IGF growth axis appears key in eliciting CG, whereby the expression levels of and sensitivity to growth-regulatory hormones is increased relative to normal animals on a continuous regimen, subsequently resulting in a hyperanabolic state characteristic of CG.

\section{THE LIPOSTATIC RETURN TO ENERGY HOMEOSTASIS}

The CG response to fasting is finite, attenuating once lost energy resources re-accumulate and hyperphagia abates. The lipostatic model of energy homeostasis proposes that adiposity acts as a regulatory mechanism on appetite in order to maintain a threshold of energy deposition (Kennedy, 1953). Kennedy observed that depletion of adipose stores in fasted rats stimulated feeding, which returned to normal levels when reserves returned to a critical mass. Studies support the presence of a teleost lipostat-like mechanism, as well, although lipid partitioning can vary considerably between adipose tissue, liver, and muscle in different fishes (Dias et al., 1999; Frøiland et al., 2012). The hyperphagic response to long-term fasting in salmonids appears to be driven by a decrease in whole body lipid content and terminates, along with the CG response, when proximate composition is restored (Jobling and Miglavs, 1993; Johansen et al., 2001). Fluctuating gross lipid levels during fasting and refeeding similarly suggest lipostatic regulation of hyperphagia in three-spined stickleback (Zhu et al., 2003) and striped bass (Turano et al., 2007) undergoing CG. The liver is a significant lipid storing and metabolizing tissue in some fish, and may also be involved in sensing and maintaining energy reserve levels. More so than visceral adipose mass, changes in the HSI during cycles of feed deprivation and refeeding in striped bass, in which liver is a major lipid storage organ, are indicative of metabolic state and the likelihood of achieving an elevated SGR, and hence CG, during refeeding (Picha et al., 2006; Turano et al., 2008).

\section{IS LEPTIN THE TELEOST LIPOSTATIC HORMONE?}

The mechanism that represents overall energetic status, endocrine or otherwise, is not well defined in teleosts, in part because different fish partition stored energy in various locations. In mammals, the anorexigenic peptide hormone, leptin, reflects fat deposition. Leptin modulates food consumption and energy expenditure according to endogenous energy availability, and is considered the primary lipostatic hormone (Ahima and Flier, 2000; Arora and Arora, 2008). If leptin functions as a lipostat in teleosts as well, it would likewise need to be indicative of energy availability. Even though leptin is consistently anorexigenic in fish as in mammals, evolutionarily isolated gene duplication events, physiological differences in energy storage and diverse life histories may underlie divergent functions for leptin in fish that only partially resemble those of higher vertebrates.

Leptin centrally regulates feeding by stimulating appetitesuppressing neuropeptides and inhibiting appetite-stimulating neuropeptides in mammals (Ahima et al., 1999; Elias et al., 1999; Zhang and Felder, 2004) and fish (Volkoff et al., 2003; Murashita et al., 2008). Leptin injection accordingly reduces feeding in goldfish (de Pedro et al., 2006), rainbow trout (Murashita et al., 2008), and striped bass (Won et al., 2012). While its anorexigenic property logically integrates into a system in which leptin serves as a lipostat, such as the mammalian paradigm, it fits less aptly into a system where leptin expression may not correlate with energy reserves, as is the case for some teleosts.

Studies evaluating leptin responsiveness to metabolic state in teleosts are equivocal. Circulating leptin (Johnson et al., 2000; Nieminen et al., 2003) or mRNA levels in liver (Gorissen et al., 2009; Won et al., 2012) are depressed in some fish during fasting, or otherwise reflect energy deposition (Kling et al., 2012). Conversely, some species exhibit rising plasma (Kling et al., 2009; Fuentes et al., 2012; Trombley et al., 2012) or gene expression levels in lipid storing tissues (Rønnestad et al., 2010; Frøiland et al., 2012; Gambardella et al., 2012; Trombley et al., 2012; Zhang et al., 2012) during feed restriction, while others show no long-term regulation by feeding regimen (Huising et al., 2006). Leptin gene expression profiles in different energy-storing tissues during altered metabolic states vary, even among closely related species, and are not necessarily concomitant with plasma levels. These studies call into question whether leptin functions as a lipostatic endocrine signal aimed at mobilizing surplus energy stores or might instead drive other catabolic processes in fish. It is important to consider that some fish possess multiple leptin genes (Huising et al., 2006; Kurokawa and Murashita, 2009; Rønnestad et al., 2010; Zhang et al., 2012) arising from different genome duplication events within lineages, and that these paralogs may have different roles. If a lipostatic function for leptin, or one form of leptin, is inherent in fish, then the replenishment of energy reserves during refeeding may eventually attenuate hyperphagia and mark the end of the CG response through leptin signaling. If not, then further studies will be needed to reconcile the paradox of rising plasma leptin levels during fasting in some fish in light of its conserved anorexigenic property.

\section{SUMMARY: SEQUENCE OF EVENTS DURING CATABOLIC AND ANABOLIC STATES LEADING TO CG}

Compensatory growth is a period of accelerated growth following the alleviation of growth-stunting conditions, such as fasting, that potentially allows an organism to make up for lost growth opportunity (Figure 1). The response can be divided into a catabolic phase, when growth is impeded and energy reserves are tapped, and a hyperanabolic phase, when growth resumes at an elevated rate. This review chronologically describes physiological adjustments and endocrine activity in fish during these metabolic phases, and suggests how they may ultimately make CG 
possible through enhanced feeding, substrate assimilation, and rapid growth.

During the precedent catabolic phase (Figure 2B), orexigens stimulate appetite as endogenous energy reserves are depleted. Ghrelin and cortisol stimulate $\mathrm{GH}$ production and elevate circulating $\mathrm{GH}$ levels in order to free energy-storing lipids. However, hepatic GH resistance and the growth-inhibitory effects of cortisol and somatostatins suppress IGF production under the pretext that conditions are unfavorable for growth. Reduced negative feedback from IGF-I further permits GH levels to rise. A critical period of catabolism is therefore required to induce hormonal changes that prime the fish for hyperphagia and super-potentiate the growth axis.

During refeeding (Figure 2C), CG is fueled by the hyperphagic influx of exogenous energy and substrates. Food is assimilated with heightened efficiency as the result of modifications to metabolic substrate absorption, in part attributable to residually elevated $\mathrm{GH}$ levels. Hepatic GHRs are reinstated and GH sensitivity returns, followed by a steep rise or even overcompensation in IGF-I production. Production of IGFs during refeeding is also influenced by a decline in growth-inhibitors. Substrate and energy availability, enhanced assimilation efficiency, and augmentation of the growth axis culminate in a hyperanabolic, rapid growth phase until a lipostat-like mechanism initiates the return to basal appetite and

\section{REFERENCES}

Agellon, L. B., Emery, C. J., Jones, J. M., Davies, S. L., Dingle, A. D., and Chen, T. T. (1988). Promotion of rapid growth of rainbow trout (Salmo gairdneri) by a recombinant fish growth hormone. Can. J. Fish. Aquat. Sci. 45, 146-151. doi:10.1139/f88-016

Ahima, R. S., and Flier, J. S. (2000). Leptin. Annu. Rev. Physiol. 62, 413-437. doi: 10.1146/annurev.physiol.62.1.413

Ahima, R. S., Kelly, J., Elmquist, J. K., and Flier, J. S. (1999). Distinct physiologic and neuronal responses to decreased leptin and mild hyperleptinemia. Endocrinology 140, 4923-4931. doi:10.1210/en.140.11.4923

Albalat, A., Gomez-Requeni, P., Rojas, P., Medale, F., Kaushik, S., Vianen, G. J., et al. (2005). Nutritional and hormonal control of lipolysis in isolated gilthead seabream (Sparus aurata) adipocytes. Am. J. Physiol. Regul. Integr. Comp. Physiol. 289, R259-R265. doi:10.1152/ajpregu.00574.2004

Aldegunde, M., and Mancebo, M. (2006). Effects of neuropeptide $\mathrm{Y}$ on food intake and brain biogenic amines in the rainbow trout (Oncorhynchus mykiss). Peptides 27, 719-727. doi:10.1016/j.peptides.2005.09.014

Alford, R. A., and Harris, R. N. (1988). Effects of larval growth history on anuran metamorphosis. Am. Nat. 131, 91-106. doi:10.1086/284775

Ali, M., Nicieza, A., and Wootton, R. J. (2003). Compensatory growth in fishes: a response to growth depression. Fish Fish. (Oxf.) 4, 147-190. doi:10.1046/j.14672979.2003.00120.x

Anderson, L. L., Jeftinija, S., Scanes, C. G., Stromer, M. H., Lee, J. S., Jeftinija, K., et al. (2005). Physiology of ghrelin and related peptides. Domest. Anim. Endocrinol. 29, 111-144. doi:10. 1016/j.domaniend.2005.02.033

Arora, A., and Arora, S. (2008). Leptin and its metabolic interactions an update. Diabetes Obes. Metab. 10, 973-993. doi:10.1111/j.14631326.2008.00852.x

Arvat, E., Maccario, M., Di Vito, L., Broglio, F., Benso, A., Gottero, C., et al. (2001). Endocrine activities of ghrelin, a natural growth hormone secretagogue (GHS), in humans: comparison and interactions with hexarelin, GH-releasing hormone. J. Clin. Endocrinol. Metab. 86, 1169-1174. doi:10.1210/jc.86.3.1169

Bagnasco, M., Kalra, P. S., and Kalra, S. P. (2002). Ghrelin and leptin pulse discharge in fed and fasted rats. Endocrinology 143, 726. doi:10.1210/en.143.2.726

Banks, W. A., Tschop, M., Robinson, S. M., and Heiman, M. L. a nonnatural peptidyl GHS, and

a growth axis profile representative of a normal growth trajectory (Figure 2A).

Compensatory growth is therefore regulated by sequential endocrine responses during distinct metabolic states (Table 1). Teleosts have been the subject of numerous CG studies; however, our understanding of their endocrine mechanisms during this phenomenon is commonly limited to observations in a few model species or extrapolations from studies in higher vertebrates. While by no means inclusive, this theoretical composite of documented hormonal activity during catabolic and anabolic states is intended to provide a basic framework of the endocrine regulation of CG in fish, and perhaps higher vertebrates. The relevance of certain hormones, time frames, and even the potential of the CG response itself are likely contingent on species, size, and life stage. Nonetheless, the variables presented in this review are estimated to be of fundamental importance to CG in fish, although the degree of their relevance in particular species may vary.

\section{ACKNOWLEDGMENTS}

This research was supported in part by the United States Department of Agriculture, North Carolina Sea Grant (R/AF-46; 0SSS-B-1), and the AquaFish Collaborative Research Support Program of the United States Agency for International Development (EPP-A-00-06-00012-00).

(2002). Extent and direction of ghrelin transport across the bloodbrain barrier is determined by its unique primary structure. J. Pharmacol. Exp. Ther. 302, 822-827. doi:10.1124/jpet.102.034827

Beckman, B. R., Shimizu, M., Gadberry, B. A., and Cooper, K. A. (2004). Response of the somatotropic axis of juvenile coho salmon to alterations in plane of nutrition with an analysis of the relationships among growth rate and circulating IGF-I and $41 \mathrm{kDa}$ IGFBP. Gen. Comp. Endocrinol. 135, 334-344. doi:10.1016/j.ygcen.2003.10.013

Bilton, H., and Robins, G. (1973). The effects of starvation and subsequent refeeding on survival and growth of Fulton channel sockeye salmon (Oncorhynchus nerka). Can. J. Fish. Aquat. Sci. 30, 1-5. doi:10.1139/f7 3-001

Bjorndal, K. A., Bolten, A. B., Dellinger, T., Delgado, C., and Martins, H. R. (2003). Compensatory Growth in Oceanic Loggerhead Sea Turtles: Response to a Stochastic Environment. Washington, DC: Ecological Society of America.

Boersma, B., and Wit, J. M. (1997). Catch-up growth. Endocr. Rev. 18, 646-661. doi:10.1210/er.18.5.646

Bohman, V. R. (1955). Compensatory growth of beef cattle: the effect of hay maturity. J. Anim. Sci. 14, 249-255.

Bull, C. D., and Metcalfe, N. B. (1997). Regulation of hyperphagia in response to varying energy deficits in overwintering juvenile Atlantic salmon. J. Fish Biol. 50, 498-510. doi:10.1111/j.10958649.1997.tb01945.x

Bull, C. D., Metcalfe, N. B., and Mangel, M. (1996). Seasonal matching of foraging to anticipated energy requirements in anorexic juvenile salmon. Philos. Trans. R. Soc. Lond. B Biol. Sci. 263, 13-18. doi:10.1098/rspb.1996.0003

Canosa, L. F., Chang, J. P., and Peter, R. E. (2007). Neuroendocrine control of growth hormone in fish. Gen. Comp. Endocrinol. 151, 1-26. doi:10.1016/j.ygcen.2006.12.010

Canosa, L. F., Unniappan, S., and Peter, R. E. (2005). Periprandial changes in growth hormone release in goldfish: role of somatostatin, ghrelin, and gastrin-releasing peptide. Am. J. Physiol. Regul. Integr. Comp. Physiol. 289, 125-133. doi:10.1152/ajpregu.00759.2004

Carnevali, O., Cardinali, M., Maradonna, F., Parisi, M., Olivotto, I., Polzonetti-Magni, A. M., et al. (2005). Hormonal regulation of hepatic IGF-I and IGF-II gene expression in the marine teleost Sparus aurata. Mol. Reprod. Dev. 71, 12-18. doi:10.1002/mrd.20122

Cavari, B., Funkenstein, B., Chen, T. T., Gonzalez-Villasenor, L. I., and Schartl, M. (1993). Effect of growth hormone on the growth rate of the gilthead seabream (Sparus aurata), 
and use of different constructs for the production of transgenic fish. Aquaculture 111, 189-197. doi:10.1016/0044-8486(93)90036-X

Cerdá-Reverter, J. M., and Peter, R. E. (2003). Endogenous melanocortin antagonist in fish: structure, brain mapping, and regulation by fasting of the goldfish agouti-related protein gene. Endocrinology 144, 4552-4561. doi:10.1210/en.2003-0453

Chan, C.-B., and Cheng, C. H. K. (2004). Identification and functional characterization of two alternatively spliced growth hormone secretagogue receptor transcripts from the pituitary of black seabream, Acanthopagrus schlegeli. Mol. Cell. Endocrinol. 214, 81-95. doi:10.1016/j.mce.2003.11.020

Chauvigne, F. (2003). Effect of refeeding on IGFI, IGFII, IGF receptors, FGF2, FGF6, and myostatin mRNA expression in rainbow trout myotomal muscle. Gen. Comp. Endocrinol. 132, 209-215. doi:10.1016/S00166480(03)00081-9

Cho, S. H. (2005). Compensatory growth of juvenile flounder Paralichthys olivaceus L. and changes in biochemical composition and body condition indices during starvation and after refeeding in winter season. J. World Aquac. Soc. 36, 508-514. doi:10.1111/j.17497345.2005.tb00398.x

Collie, N. L., and Stevens, J. J. (1985). Hormonal effects on Lproline transport in coho salmon (Oncorhynchus kisutch) intestine. Gen. Comp. Endocrinol. 59, 399-409. doi:10.1016/0016-6480(85)90397-1

Cummings, D. E., Frayo, R. S., Marmonier, C., Aubert, R., and Chapelot, D. (2004). Plasma ghrelin levels and hunger scores in humans initiating meals voluntarily without time- and food-related cues. Am. J. Physiol. Endocrinol. Metab. 287, E297-E304. doi:10.1152/ajpendo.00582.2003

Date, Y., Murakami, N., Toshinai, K., Matsukura, S., Niijima, A., Matsuo, H., et al. (2002). The role of the gastric afferent vagal nerve in ghrelin-induced feeding and growth hormone secretion in rats. Gastroenterology 123, 1120-1128. doi:10.1053/gast.2002.35954

de Celis, S. V. R., Gomez, P., CalduchGiner, J. A., Medale, F., and PerezSanchez, J. (2003). Expression and characterization of European sea bass (Dicentrarchus labrax) somatolactin: assessment of in vivo metabolic effects. Mar. Biotechnol. 5, 92-101. doi:10.1007/s10126-0020053-6 de Pedro, N., Céspedes, M. V., Delgado, M. J., and Alonso-Bedate, M. (1995). The galanin-induced feeding stimulation is mediated via $\alpha 2$-adrenergic receptors in goldfish. Regul. Pept. 57, 77-84. doi:10.1016/0167-0115(95)91255-4

de Pedro, N., Martinez-Alvarez, R., and Delgado, M. J. (2006). Acute and chronic leptin reduces food intake and body weight in goldfish (Carassius auratus). J. Endocrinol. 188, 513-520. doi:10.1677/joe.1.06349

Deng, L., Zhang, W. M., Lin, H. R. and Cheng, C. H. (2004). Effects of food deprivation on expression of growth hormone receptor and proximate composition in liver of black seabream Acanthopagrus schlegeli. Comp. Biochem. Physiol. B Biochem. Mol. Biol. 137, 421-432. doi:10.1016/j.cbpc.2004.01.008

Dias, J., Corraze, G., Arzel, J., Alvarez, M. J., Bautista, J. M., Lopez-Bote, C., et al. (1999). Nutritional control of lipid deposition in rainbow trout and European seabass: effect of dietary protein energy ratio. Cybium 23, 127-137.

Dobson, S. H., and Holmes, R. M. (1984). Compensatory growth in the rainbow trout, Salmo gairdneri Richardson. J. Fish Biol. 25, 649-656. doi:10.1111/j.10958649.1984.tb04911.x

Duan, C. (1998). Nutritional and developmental regulation of insulin-like growth factors in fish. J. Nutr. 128, 306S-314S.

Duan, C., and Plisetskaya, E. M. (1993). Nutritional regulation of insulin-like growth factor-I mRNA expression in salmon tissues. J. Endocrinol. 139, 243-252. doi:10.1677/joe.0.1390243

Duguay, S. J., Lai-Zhang, J., Steiner, D. F., Funkenstein, B., and Chan, S. J. (1996). Developmental and tissueregulated expression of IGF-I and IGF-II mRNAs in Sparus aurata. J. Mol. Endocrinol. 16, 123-132. doi:10.1677/jme.0.0160123

Dyer, A. R., Upton, Z., Stone, D., Thomas, P. M., Soole, K. L., Higgs, N., et al. (2004). Development and validation of a radioimmunoassay for fish insulin-like growth factor I (IGF-I) and the effect of aquaculture related stressors on circulating IGF-I levels. Gen. Comp. Endocrinol. 135, 268-275. doi:10.1016/j.ygcen.2003.10.002

Elias, C. F., Aschkenasi, C., Lee, C., Kelly, J., Ahima, R. S., Bjorbæk, C., et al. (1999). Leptin differentially regulates NPY and POMC neurons projecting to the lateral hypothalamic area. Neuron 23, 775-786. doi:10.1016/S08966273(01)80035-0

Farbridge, K. J., and Leatherland, J. F. (1992). Plasma growth hormone levels in fed and fasted rainbow trout (Oncorhynchus mykiss) are decreased following handling stress. Fish Physiol. Biochem. 10, 67-73. doi:10.1007/BF00004655

Ferrando, S., Gambardella, C., Bottaro, M., Saroglia, M., Terova, G. and Tagliafierro, G. (2009). The compensatory growth in juveniles of sea bass: gastric distributive pattern of molecules regulating metabolism. Ann. N. Y. Acad. Sci. 1163, 389-393. doi:10.1111/j.17496632.2009.04458.x

Fine, M., Sakal, E., Vashdi, D., Daniel, V., Levanon, A., Lipshitz, O., et al. (1993). Recombinant carp (Cyprinus carpio) growth hormone: expression, purification, and determination of biological activity in vitro and in vivo. Gen Comp. Endocrinol. 89, 51-61. doi:10.1006/gcen.1993.1008

Foster, A. R., Houlihan, D. F., Gray, C., Medale, F., Fauconneau, B. Kaushikj, S. J., et al. (1991). The effects of ovine growth hormone on protein turnover in rainbow trout. Gen. Comp. Endocrinol. 82, 111-120. doi:10.1016/0016-6480(91)90 302-M

Fox, B. K., Riley, L. G., Dorough, C. Kaiya, H., Hirano, T., and Grau, E. G. (2007). Effects of homologous ghrelins on the growth hormone/insulin-like growth factor-I axis in the tilapia, Oreochromis mossambicus. Zool. Sci. 24 391-400. doi:10.2108/zsj.24.391

Froesch, E. R., Schmid, C., Schwander, J., and Zapf, J. (1985). Actions of insulin-like growth factors. Annu. Rev. Physiol. 47, 443-467i. doi:10. 1146/annurev.ph.47.030185.002303

Frøiland, E., Jobling, M., Björnsson, B. T., Kling, P., Ravuri, C. S., and Jørgensen, E. H. (2012). Seasonal appetite regulation in the anadromous Arctic charr: evidence for a role of adiposity in the regulation of appetite but not for leptin in signalling adiposity. Gen. Comp. Endocrinol. 178, 330-337. doi:10.1016/j.ygcen

Fruchtman, S., Jackson, L., and Borski, R. (2000). Insulin-like growth factor I disparately regulates prolactin and growth hormone synthesis and secretion: studies using the teleost pituitary model. Endocrinology 141, 2886-2894. doi:10.1210/en.141.8.2886
Fuentes, E. N., Björnsson, B. T., Valdés, J. A., Einarsdottir, I. E., Lorca, B., Alvarez, M., et al. (2011). IGF-I/PI3K/Akt and IGFI/MAPK/ERK pathways in vivo in skeletal muscle are regulated by nutrition and contribute to somatic growth in the fine flounder. Am. J. Physiol. Regul. Integr. Comp. Physiol. 300, R1532-R1542. doi:10.1152/ajpregu.00535.2010

Fuentes, E. N., Kling, P., Einarsdottir, I. E., Alvarez, M., Valdés, J. A., Molina, A., et al. (2012). Plasma leptin and growth hormone levels in the fine flounder (Paralichthys adspersus) increase gradually during fasting and decline rapidly after refeeding. Gen. Comp. Endocrinol. 177, 120-127. doi:10.1016/j.ygcen.2012.02.019

Fukada, H., Ozaki, Y., Pierce, A. L., Adachi, S., Yamauchi, K., Hara, A., et al. (2004). Salmon growth hormone receptor: molecular cloning, ligand specificity, and response to fasting. Gen. Comp. Endocrinol. 139, 61-71. doi:10.1016/j.ygcen.2004.07.001

Fukada, H., Ozaki, Y., Pierce, A. L., Adachi, S., Yamauchi, K., Hara, A., et al. (2005). Identification of the salmon somatolactin receptor, a new member of the cytokine receptor family. Endocrinology 146, 2354-2361. doi:10.1210/en.2004-1578

Fukamachi, S., and Meyer, A. (2007). Evolution of receptors for growth hormone and somatolactin in fish and land vertebrates: lessons from the lungfish and sturgeon orthologues. J. Mol. Evol. 65, 359-372. doi:10.1007/s00239-007-9035-7

Gabillard, J. C., Kamangar, B. B., and Montserrat, N. (2006). Coordinated regulation of the GH/IGF system genes during refeeding in rainbow trout (Oncorhynchus mykiss). J. Endocrinol. 191, 15-24. doi:10.1677/joe.1.06869

Gambardella, C., Gallus, L., Amaroli, A., Terova, G., Masini, M. A., and Ferrando, S. (2012). Fasting and re-feeding impact on leptin and aquaglyceroporin 9 in the liver of European sea bass (Dicentrarchus labrax). Aquaculture 35, 1-6. doi:10. 1016/j.aquaculture.2012.04.043

Gaylord, I. G., and Gatlin, D. M. (2000). Assessment of compensatory growth in channel catfish Ictalurus punctatus R. and associated changes in body condition indices. J. World Aquac. Soc 31, 326-336. doi:10.1111/j.17497345.2000.tb00884.x

Gorissen, M., Bernier, N. J., Nabuurs, S. B., Flik, G., and Huising, M. O. 
(2009). Two divergent leptin paralogues in zebrafish (Danio rerio) that originate early in teleostean evolution. J. Endocrinol. 201, 329-339. doi:10.1677/JOE-09-0034

Gray, E. S., Kelley, K. M., Law, S., Tsai, R., Young, G., and Bern, H. A. (1992). Regulation of hepatic growth hormone receptors in coho salmon (Oncorhynchus kisutch). Gen. Comp. Endocrinol. 88, 243-252. doi:10.1016/0016-6480(92)90256-J

Gurney, W. S. C., Jones, W., Veitch, A. R., and Nisbet, R. M. (2003). Resource allocation, hyperphagia and compensatory growth in juveniles. Ecology 84, 2777-2787. doi:10.1890/020536

Hataya, Y., Akamizu, T., Takaya, K., Kanamoto, N., Ariyasu, H., Saijo, M., et al. (2001). A low dose of ghrelin stimulates growth hormone (GH) release synergistically with ghreleasing hormone in humans. J. Clin. Endocrinol. Metab. 86, 45524552. doi:10.1210/jc.86.9.4552

Hayward, R. S., Noltie, D. B., and Wang, N. (1997). Use of compensatory growth to double hybrid sunfish growth rates. Trans. Am. Fish. Soc. 126, 316-322. doi:10.1577/15488659(1997)126<0316:NUOCGT> 2.3.CO;2

Heide, A., Foss, A., Stefansson, S. O., Mayer, I., Norberg, B., Roth, B., et al. (2006). Compensatory growth and fillet crude composition in juvenile Atlantic halibut: effects of short term starvation periods and subsequent feeding. Aquaculture 261, 109-117. doi:10.1016/j.aquaculture.2006.06.050

Huising, M. O., Geven, E. J. W., Kruiswijk, C. P., Nabuurs, S. B., Stolte, E. H., Spanings, F. A. T., et al. (2006). Increased leptin expression in common carp (Cyprinus carpio) after food intake but not after fasting or feeding to satiation. Endocrinology 147, 5786-5797. doi:10.1210/en.2006-0824

Jiao, B., Huang, X., Chan, C. B., Zhang, L., Wang, D., and Cheng, C. H. K. (2006). The co-existence of two growth hormone receptors in teleost fish and their differential signal transduction, tissue distribution and hormonal regulation of expression in seabream. J. Mol. Endocrinol. 36, 23-40. doi:10.1677/jme.1.01945

Jobling, M., and Johansen, S. (1999). The lipostat, hyperphagia and catch-up growth. Aquac. Res. 30, 473-478. doi:10.1046/j.13652109.1999.00358.x

Jobling, M., Jørgensen, E. H., and Siikavuopio, S. I. (1993). The influence of previous feeding regime on the compensatory growth response of maturing and immature Arctic charr, Salvelinus alpinus. J. Fish Biol. 43, 409-419. doi:10.1111/j.10958649.1993.tb00576.x

Jobling, M., Meløy, O. H., Santos, J., and Christiansen, B. (1994). The compensatory growth response of the Atlantic cod: effects of nutritional history. Aquac. Int. 2, 75-90. doi:10.1007/BF00128802

Jobling, M., and Miglavs, I. (1993). The size of lipid depots-a factor contributing to the control of food intake in Arctic charr, Salvelinus alpinus. J. Fish Biol. 43, 487-489. doi:10.1111/j.10958649.1993.tb00583.x

Johansen, S. J. S., Ekli, M., Stangnes, B., and Jobling, M. (2001). Weight gain and lipid deposition in Atlantic salmon, Salmo salar, during compensatory growth: evidence for lipostatic regulation? Aquac. Res. 32, 963-974. doi:10.1046/j.13652109.2001.00632.x

Johnson, R. M., Johnson, T. M., and Londraville, R. L. (2000). Evidence for leptin expression in fishes. J. Exp. Zool. 286, 718-724. doi:10.1002/(SICI)1097$010 X(20000601) 286: 7<718:$ AIDJEZ6>3.0.CO;2-I

Jönsson, E., Forsman, A., Einarsdottir, I. E., Kaiya, H., Ruohonen, K., and Björnsson, B. T. (2007). Plasma ghrelin levels in rainbow trout in response to fasting, feeding and food composition, and effects of ghrelin on voluntary food intake. Comp. Biochem. Physiol. A Mol. Integr. Physiol. 147, 1116-1124. doi:10.1016/j.cbpa.2007.03.024

Jönsson, E., Kaiya, H., and Björnsson, B. T. (2010). Ghrelin decreases food intake in juvenile rainbow trout (Oncorhynchus mykiss) through the central anorexigenic corticotropinreleasing factor system. Gen. Comp. Endocrinol. 166, 39-46. doi:10.1016/j.ygcen.2009.11.001

Kaiya, H., Kojima, M., Hosoda, H., Moriyama, S., Takahashi, A., Kawauchi, H., et al. (2003a). Peptide purification, complementary deoxyribonucleic acid (DNA) and genomic DNA cloning, and functional characterization of ghrelin in rainbow trout. Endocrinology 144, 5215-5226. doi:10.1210/en.2003-1085

Kaiya, H., Kojima, M., Hosoda, H., Riley, L. G., Hirano, T., Grau, E. G., et al. (2003b). Amidated fish ghrelin: purification, cDNA cloning in the Japanese eel and its biological activity. J. Endocrinol. 176, 415-423. doi:10.1677/joe.0.176 0415
Kaiya, H., Kojima, M., Hosoda, H., Riley, L. G., Hirano, T., Grau, E. G., et al. (2003c). Identification of tilapia ghrelin and its effects on growth hormone and prolactin release in the tilapia, Oreochromis mossambicus. Comp. Biochem. Physiol. B Biochem. Mol. Biol. 135, 421-429. doi:10. 1016/S1096-4959(03)00109-X

Kaiya, H., Miyazato, M., Kangawa, K., Peter, R. E., and Unniappan, S. (2008). Ghrelin: a multifunctional hormone in non-mammalian vertebrates. Comp. Biochem. Physiol. A Mol. Integr. Physiol. 149, 109-128. doi:10.1016/j.cbpa.2007.12.004

Kajimura, S., Hirano, T., Visitacion, N. Moriyama, S., Aida, K., and Grau, E. (2003). Dual mode of cortisol action on GH/IGF-I/IGF binding proteins in the tilapia, Oreochromis mossambicus. J. Endocrinol. 178, 91-99. doi:10.1677/joe.0.1780091

Kalra, S. P., Dube, M. G., Pu, S., Xu, B., Horvath, T. L., and Kalra, P. S. (1999). Interacting appetite-regulating pathways in the hypothalamic regulation of body weight. Endocr. Rev. 20, 68-100. doi:10.1210/er.20.1.68

Kennedy, G. C. (1953). The role of depot fat in the hypothalamic control of food intake in the rat. Proc. $R$. Soc. Lond. B Biol. Sci. 140, 578-592. doi:10.1098/rspb.1953.0009

Kiris, G. A., Kumlu, M., and Dikel, S. (2007). Stimulatory effects of neuropeptide $\mathrm{Y}$ on food intake and growth of Oreochromis niloticus. Aquaculture 264, 383-389. doi:10.1016/j.aquaculture.2006. 12.004

Kittilson, J., Jones, E., and Sheridan, M. (2011). ERK, Akt, and STAT5 are differentially activated by the two growth hormone receptors subtypes of a teleost fish (Oncorhynchus mykiss). Front. Endocrinol. 2:30. doi: $10.3389 /$ fendo.2011.00030

Kling, P., Jönsson, E., Nilsen, T. O., Einarsdottir, I. E., Rønnestad, I., Stefansson, S. O., et al. (2012). The role of growth hormone in growth, lipid homeostasis, energy utilization and partitioning in rainbow trout: Interactions with leptin, ghrelin and insulin-like growth factor I. Gen. Comp. Endocrinol. 175, 153-162. doi:10.1016/j.ygcen.2011.10.014

Kling, P., Rønnestad, I., Stefansson, S. O., Murashita, K., Kurokawa, T., and Björnsson, B. T. (2009). A homologous salmonid leptin radioimmunoassay indicates elevated plasma leptin levels during fasting of rainbow trout. Gen. Comp. Endocrinol. 162, 307-312. doi:10.1016/j.ygcen.2009.04.003
Kojima, M., Hosoda, H., Date, Y., Nakazato, M., Matsuo, H., and Kangawa, K. (1999). Ghrelin is a growthhormone-releasing acylated peptide from stomach. Nature 402, 656-660. doi:10.1038/45230

Kurokawa, T., and Murashita, K. (2009). Genomic characterization of multiple leptin genes and a leptin receptor gene in the Japanese medaka, Oryzias latipes. Gen. Comp. Endocrinol. 161, 229-237. doi:10.1016/j.ygcen.2009.01.008

Leonard, J. B., Waldbieser, G. C., and Silverstein, J. T. (2001) Neuropeptide $\mathrm{Y}$ sequence and messenger RNA distribution in channel catfish (Ictalurus punctatus). Mar. Biotechnol. 3, 111-118. doi:10.1007/s101260000050

Leung, L. Y., Kwong, A. K. Y., Man, A. K. Y., and Woo, N. Y. S. (2008). Direct actions of cortisol, thyroxine and growth hormone on IGF-I mRNA expression in sea bream hepatocytes. Comp. Biochem. Physiol. A Mol. Integr. Physiol. 151, 705-710. doi:10.1016/j.cbpa.2008.08.023

Lin, X., Volkoff, H., Narnaware, Y., Bernier, N. J., Peyon, P., and Peter, R. E. (2000). Brain regulation of feeding behavior and food intake in fish. Comp. Biochem. Physiol. A Mol. Integr. Physiol. 126, 415-434. doi:10.1016/S10956433(00)00230-0

Lopez-Patino, M. A., Guijarro, A. I., Isorna, E., Delgado, M. J., Alonso-Bedate, M., and De Pedro, N. (1999). Neuropeptide $\mathrm{Y}$ has a stimulatory action on feeding behavior in goldfish (Carassius auratus). Eur. J. Pharmacol. 377, 147-153. doi:10.1016/S00142999(99)00408-2

MacKenzie, D. S., Vanputte, C. M., and Leiner, K. A. (1998). Nutrient regulation of endocrine function in fish. Aquaculture 161, 3-25. doi:10. 1016/S0044-8486(97)00253-6

Maclean, A., and Metcalfe, N. B. (2001). Social status, access to food, and compensatory growth in juvenile Atlantic salmon. J. Fish Biol. 58, 1331-1346. doi:10.1111/j.10958649.2001.tb02290.x

Markert, J. R., Higgs, D. A., Dye, H. M., and Macquarrie, D. W. (1977). Influence of bovine growth hormone on growth rate, appetite, and food conversion of yearling coho salmon (Oncorhynchus kisutch) fed two diets of different composition. Can. J. Zool.55,74-83. doi:10.1139/z77-008 Matsuda, K., Miura, T., Kaiya, H., Maruyama, K., Shimakura, S.I., Uchiyama, M., et al. (2006). Regulation of food intake by 
acyl and des-acyl ghrelins in the goldfish. Peptides 27, 2321-2325. doi:10.1016/j.peptides.2006.03.028

Mersmann, H. J., Macneil, M. D., Seideman, S. C., and Pond, W. G. (1987). Compensatory growth in finishing pigs after feed restriction. J. Anim. Sci. 64, 752-764.

Metcalfe, N. B., Huntingford, F. A., and Thorpe, J. E. (1986). Seasonal changes in feeding motivation of juvenile Atlantic salmon (Salmo salar). Can. J. Zool. 64, 2439-2446. doi:10.1139/z86-364

Metcalfe, N. B., and Thorpe, J. E. (1992). Anorexia and defended energy levels in over-wintering juvenile salmon. J. Anim. Ecol. 61, 175-181. doi:10.2307/5520

Mingarro, M., Vega-RubíN De Celis, S., Astola, A., Pendón, C., Valdivia, M. M. N., and PérezSánchez, J. (2002). Endocrine mediators of seasonal growth in gilthead sea bream (Sparus aurata): the growth hormone and somatolactin paradigm. Gen. Comp. Endocrinol. 128, 102-111. doi:10.1016/S00166480(02)00042-4

Miura, T., Maruyama, K., Shimakura, S., Kaiya, H., Uchiyama, M., Kangawa, K., et al. (2006). Neuropeptide $\mathrm{Y}$ mediates ghrelin-induced feeding in the goldfish, Carassius auratus. Neurosci. Lett. 407, 279-283. doi:10.1016/j.neulet.2006.08.071

Mommsen, T. P. (2001). Paradigms of growth in fish. Comp. Biochem. Physiol. B Biochem. Mol. Biol. 129, 207-219. doi:10.1016/S10964959(01)00312-8

Mommsen, T. P., Vijayan, M. M., and Moon, T. W. (1999). Cortisol in teleosts: dynamics, mechanisms of action, and metabolic regulation. Rev. Fish Biol. Fish. 9, 211-268. doi:10.1023/A:1008924418720

Montserrat, N., Gabillard, J. C., Capilla, E., Navarro, M. I., and Gutierrez, J. (2007a). Role of insulin, insulin-like growth factors, and muscle regulatory factors in the compensatory growth of the trout (Oncorhynchus mykiss). Gen. Comp. Endocrinol. 150, 462-472. doi:10.1016/j.ygcen.2006.11.009

Montserrat, N., Gómez-Requeni, P., Bellini, G., Capilla, E., PérezSánchez, J., Navarro, I., et al. (2007b). Distinct role of insulin and IGF-I and its receptors in white skeletal muscle during the compensatory growth of gilthead sea bream (Sparus aurata). Aquaculture 267, 188-198. doi:10.1016/j.aquaculture.2007. 04.024

Mori, I., Sakamoto, T., and Hirano, T. (1992). Growth hormone
(GH)-dependent hepatic GH receptors in the Japanese eel, Anguilla japonica: effects of hypophysectomy and GH injection. Gen. Comp. Endocrinol. 85, 385-391. doi:10.1016/0016-6480(92)90083-V

Moriyama, S., Oda, M., Yamazaki, T., Yamaguchi, K., Amiya, N., Takahashi, A., et al. (2008a). Gene structure and functional characterization of growth hormone in dogfish, Squalus acanthias. Zool. Sci. 25, 604-613. doi:10.2108/zsj.25.604

Moriyama, S., Yamaguchi, K., Takasawa, T., Chiba, H., and Kawauchi, H. (2008b). Identification of two insulin-like growth factor IIs in the Japanese eel, Anguilla japonica: cloning, tissue distribution, and expression after growth hormone treatment and seawater acclimation. Comp. Biochem. Physiol. B Biochem. Mol. Biol. 149, 47-57. doi:10.1016/j.cbpb.2007.08.005

Murashita, K., Uji, S., Yamamoto, T., Rønnestad, I., and Kurokawa, T. (2008). Production of recombinant leptin and its effects on food intake in rainbow trout (Oncorhynchus mykiss). Comp. Biochem. Physiol. B Biochem. Mol. Biol. 150, 377-384. doi:10.1016/j.cbpb.2008.04.007

Nakazato, M., Murakami, N., Date, Y., Kojima, M., Matsuo, H., Kangawa, K., et al. (2001). A role for ghrelin in the central regulation of feeding. Nature 409, 194-198. doi:10.1038/35051587

Narnaware, Y. K., Peyon, P. P., Lin, X., and Peter, R. E. (2000). Regulation of food intake by neuropeptide $\mathrm{Y}$ in goldfish. Am. J. Physiol. Regul. Integr. Comp. Physiol. 279, R1025-R1034.

Nieminen, P., Mustonen, A.-M., and Hyvärinen, H. (2003). Fasting reduces plasma leptin- and ghrelin-immunoreactive peptide concentrations of the burbot (Lota lota) at $2^{\circ} \mathrm{C}$ but not at $10^{\circ} \mathrm{C}$. Zool. Sci. 20, 1109-1115. doi:10.2108/zsj.20.1109

Nikki, J., Pirhonen, J., Jobling, M., and Karjalainen, J. (2004). Compensatory growth in juvenile rainbow trout, Oncorhynchus mykiss (Walbaum), held individually. Aquaculture 235, 285-296. doi:10.1016/j.aquaculture.2003. 10.017

Nishioka, R. S., Grau, E. G., and Bern, H. A. (1985). In vitro release of growth hormone from the pituitary gland of tilapia, Oreochromis mossambicus. Gen. Comp. Endocrinol. 60, 90-94. doi:10.1016/0016-6480(85)90297-7

Norbeck, L. A., Kittilson, J. D., and Sheridan, M. A. (2007). Resolving the growth-promoting and metabolic effects of growth hormone: differential regulation of $\mathrm{GH}$ IGF-I system components. Gen Comp. Endocrinol. 151, 332-341. doi:10.1016/j.ygcen.2007.01.039

Osborne, T. B., and Mendel, L. B. (1916). Acceleration of growth after retardation. Am. J. Physiol. 40, 16-20.

Peng, C., Chang, J. P., Yu, K. L., Wong, A. O., van Goor, F., Peter, R. E., et al. (1993). Neuropeptide-Y stimulates growth hormone and gonadotropinII secretion in the goldfish pituitary: involvement of both presynaptic and pituitary cell actions. Endocrinology 132, 1820-1829. doi:10.1210/en.132.4.1820

Peng, C., Gallin, W., Peter, R. E., Blomqvist, A. G., and Larhammar, D. (1994). Neuropeptide-Y gene expression in the goldfish brain: distribution and regulation by ovarian steroids. Endocrinology 134, 1095-1103. doi:10.1210/en.134.3.1095

Perez-Sanchez, J., and Le Bail, P. Y. (1999). Growth hormone axis as marker of nutritional status and growth performance in fish. Aquaculture 117, 117-128. doi:10. 1016/S0044-8486(99)00073-3

Pérez-Sánchez, J., Martí-Palanca, H., and Le Bail, P. Y. (1994). Homologous growth hormone (GH) binding in gilthead sea bream (Sparus aurata). Effect of fasting and refeeding on hepatic GH-binding and plasma somatomedin-like immunoreactivity. J. Fish Biol. 44, 287-301. doi:10.1111/j.10958649.1994.tb01206.x

Peter, R. E., and Marchant, T. A. (1995). The endocrinology of growth in carp and related species. Aquaculture 129, 299-321. doi:10.1016/00448486(94)00302-5

Picha, M. E., Silverstein, J. T., and Borski, R. J. (2006). Discordant regulation of hepatic IGF-I mRNA and circulating IGF-I during compensatory growth in a teleost, the hybrid striped bass (Morone chrysops $\times$ Morone saxatilis). Gen. Comp. Endocrinol. 147, 196-205. doi:10.1016/j.ygcen.2005.12.020

Picha, M. E., Strom, C. N., Riley, L. G., Walker, A. A., Won, E. T., Johnstone, W. M., et al. (2009). Plasma ghrelin and growth hormone regulation in response to metabolic state in hybrid striped bass: effects of feeding, ghrelin and insulinlike growth factor-I on in vivo and in vitro GH secretion. Gen. Comp. Endocrinol. 161, 365-372. doi:10.1016/j.ygcen.2009.01.026

Picha, M. E., Turano, M. J., Beckman, B. R., and Borski, R. J. (2008a).
Endocrine biomarkers of growth and applications to aquaculture: a minireview of growth hormone, insulin-like growth factor (IGF)$\mathrm{I}$, and IGF-binding proteins as potential growth indicators in fish. N. Am. J. Aquac. 70, 196-211. doi:10.1577/A07-038.1

Picha, M. E., Turano, M. J., Tipsmark, C. K., and Borski, R. J. (2008b). Regulation of endocrine and paracrine sources of Igfs and Gh receptor during compensatory growth in hybrid striped bass (Morone chrysops $\times$ Morone saxatilis). J. Endocrinol. 199, 81-94. doi:10.1677/JOE-07-0649

Pierce, A. L., Breves, J. P., Moriyama, S., Hirano, T., and Grau, E. G. (2011) Differential regulation of Igfl and Igf2 mRNA levels in tilapia hepatocytes: effects of insulin and cortisol on GH sensitivity. J. Endocrinol. 211, 201-210. doi:10.1530/JOE-10-0456

Pierce, A. L., Fox, B. K., Davis, L. K., Visitacion, N., Kitahashi, T., Hirano, T., et al. (2007). Prolactin receptor, growth hormone receptor, and putative somatolactin receptor in Mozambique tilapia: tissue specific expression and differential regulation by salinity and fasting. Gen. Comp. Endocrinol. 154, 31-40. doi:10.1016/j.ygcen.2007.06.023

Prader, A., Tanner, J. M., and Harnack, G. A. V. (1963). Catch-up growth following illness or starvation - an example of developmental canalization in man. J. Pediatr. 62, 646-659. doi:10.1016/S00223476(63)80035-9

Radder, R. S., Warner, D. A., and Shine, R. (2007). Compensating for a bad start: catch-up growth in juvenile lizards (Amphibolurus muricatus, agamidae). J. Exp. Zool. A Ecol. Genet. Physiol. 307A, 500-508. doi:10.1002/jez.403

Ran, X., Li, W., and Lin, H. (2004). Rat ghrelin stimulates $\mathrm{GH}$ release and GH mRNA expressionin the pituitary of orange-spotted grouper, Epinephelus coioides. Fish Physiol. Biochem. 30, 95-102. doi:10.1007/s10695-005-1768-x

Reinecke, M., and Collet, C. (1998). "The phylogeny of the insulinlike growth factors," in International Review of Cytology, ed. K. W. Jeon (San Diego: Elsevier Academic Press), 1-94.

Riley, L. G., Fox, B. K., Breves, J. P., Kaiya, H., Dorough, C. P., Hirano, T., et al. (2008). Absence of effects of short-term fasting on plasma ghrelin and brain expression of ghrelin receptors in the tilapia, Oreochromis mossambicus. Zool. Sci. 25, 821-827. doi:10.2108/zsj.25.821 
Riley, L. G., Fox, B. K., Kaiya, H., Hirano, T., and Grau, E. G. (2005). Longterm treatment of ghrelin stimulates feeding, fat deposition, and alters the GH/IGF-I axis in the tilapia, Oreochromis mossambicus. Gen. Comp. Endocrinol. 142, 234-240. doi:10.1016/j.ygcen.2005.01.009

Rønnestad, I., Nilsen, T. O., Murashita, K., Angotzi, A. R., Gamst Moen, A.-G., Stefansson, S. O., et al. (2010). Leptin and leptin receptor genes in Atlantic salmon: cloning, phylogeny, tissue distribution and expression correlated to long-term feeding status. Gen. Comp. Endocrinol. 168, 55-70. doi:10.1016/j.ygcen.2010.04.010

Russell, N. R., and Wootton, R. J. (1992). Appetite and growth compensation in the european minnow, phoxinusphoxinus (Cyprinidae), following short periods of food restriction. Environ. Biol. Fishes 34, 277-285. doi:10.1007/BF00004774

Ryan, W. J. (1990). Compensatory growth in cattle and sheep. Nutr. Abstr. Rev. 60, 653-664.

Saera-Vila, A., Calduch-Giner, J.-A., and Pérez-Sánchez, J. (2005). Duplication of growth hormone receptor (GHR) in fish genome: gene organization and transcriptional regulation of GHR type I and II in gilthead sea bream (Sparus aurata). Gen. Comp. Endocrinol. 142, 193-203. doi:10.1016/j.ygcen.2004.11.005

Sapolsky, R. M. (1998). Why Zebras Don't Get Ulcers: An Updated Guide to Stress, Stress-related Diseases, and Coping. New York: W.H. Freeman and Co.

Schwartz, M. W., Woods, S. C., Porte, D. Jr., Seeley, R. J., and Baskin, D. G. (2000). Central nervous system control of food intake. Nature 404, 661-671.

Shamblott, M. J., Cheng, C. M., Bolt, D., and Chen, T. T. (1995). Appearance of insulin-like growth factor mRNA in the liver and pyloric ceca of a teleost in response to exogenous growth hormone. Proc. Natl. Acad. Sci. U.S.A. 92, 6943-6946. doi:10.1073/pnas.92.15.6943

Shepherd, B. S., Johnson, J. K., Silverstein, J. T., Parhar, I. S., Vijayan, M. M., McGuire, A., et al. (2007). Endocrine and orexigenic actions of growth hormone secretagogues in rainbow trout (Oncorhynchus mykiss). Comp. Biochem. Physiol. A Mol. Integr. Physiol. 146, 390-399. doi:10.1016/j.cbpa.2006.11.004

Sheridan, M. A. (1986). Effects of thyroxin, cortisol, growth hormone, and prolactin on lipid metabolism of coho salmon, Oncorhynchus kisutch, during smoltification. Gen. Comp. Endocrinol. 64, 220-238. doi:10.1016/0016-6480(86)90007-9

Sheridan, M. A., and Kittilson, J. D. (2004). The role of somatostatins in the regulation of metabolism in fish. Comp. Biochem. Physiol. B Biochem. Mol. Biol. 138, 323-330. doi:10.1016/j.cbpc.2004.04.006

Silverstein, J. T., Breininger, J., Baskin, D. G., and Plisetskaya, E. M. (1998). Neuropeptide Y-like gene expression in the salmon brain increases with fasting. Gen. Comp. Endocrinol. 110, 157-165. doi:10.1006/gcen.1998.7058

Skalski, G. T., Picha, M. E., Gilliam, J. F., and Borski, R. J. (2005). Variable intake, compensatory growth, and increased growth efficiency in fish: models and mechanisms. Ecology 86, 1452-1462. doi:10.1890/04-0896

Small, B. C., Murdock, C. A., Waldbieser, G. C., and Peterson, B. C. (2006). Reduction in channel catfish hepatic growth hormone receptor expression in response to food deprivation and exogenous cortisol. Domest. Anim. Endocrinol. 31, 340-356. doi:10.1016/j.domaniend.2005.12.003

Small, B. C., and Peterson, B. C. (2005). Establishment of a time-resolved fluoroimmunoassay for measuring plasma insulin-like growth factor I (IGF-I) in fish: effect of fasting on plasma concentrations and tissue mRNA expression of IGFI and growth hormone (GH) in channel catfish (Ictalurus punctatus). Domest. Anim. Endocrinol. 28, 202-215.

Stephens, T., Basinski, M., Bristow, P., Bue-Valleskey, J., Burgett, S., Craft, L., et al. (1995). The role of neuropeptide $\mathrm{Y}$ in the antiobesity action of the obese gene product. Nature 377, 530-532. doi:10.1038/377530a0

Sumpter, J., Le Bail, P., Pickering, A., Pottinger, T., and Carragher, J. (1991). The effect of starvation on growth and plasma growth hormone concentrations of rainbow trout, Oncorhynchus mykiss. Gen. Comp. Endocrinol. 83, 94-102. doi:10.1016/0016-6480(91)90110-R

Sun, L. Z., and Farmanfarmaian, A. (1992). Biphasic action of growth hormone on intestinal amino acid absorption in striped bass hybrids. Comp. Biochem. Physiol. A Physiol. 103, 381-390. doi:10.1016/03009629(92)90598-K

Tannenbaum, G. S., and Bowers, C. Y. (2001). Interactions of growth hormone secretagogues and growth hormone-releasing hormone/somatostatin. Endocrine 14, 21-27. doi:10.1385/ENDO:14:1:021
Tannenbaum, G. S., Epelbaum, J., and Bowers, C. Y. (2003). Interrelationship between the novel peptide ghrelin and somatostatin/growth hormone-releasing hormone in regulation of pulsatile growth hormone secretion. Endocrinology 144, 967-974. doi:10.1210/en.2002-220852

Terova, G., Rimoldi, S., Bernardini, G., Gornati, R., and Saroglia, M. (2008). Sea bass ghrelin: molecular cloning and mRNA quantification during fasting and refeeding. Gen. Comp. Endocrinol. 155, 341-351. doi:10.1016/j.ygcen.2007.05.028

Terova, G., Rimoldi, S., Chini, V., Gornati, R., Bernardini, G., and Saroglia, M. (2007). Cloning and expression analysis of insulin-like growth factor I and II in liver and muscle of sea bass (Dicentrarchus labrax, L.) during long-term fasting and refeeding. J. Fish Biol. 70, 219-233. doi:10.1111/j.10958649.2007.01402.x

Toguyeni, A., Baroiller, J.-F., Fostier, A., Le Bail, P.-Y., Kahn, E. R., Mol, K. A., et al. (1996). Consequences of food restriction on short-term growth variation and on plasma circulating hormones in Oreochromis niloticus in relation to sex. Gen. Comp. Endocrinol. 103, 167-175. doi:10.1006/gcen.1996.0107

Trombley, S., Maugars, G., Kling, P., Björnsson, B. T., and Schmitz, M. (2012). Effects of long-term restricted feeding on plasma leptin, hepatic leptin expression and leptin receptor expression in juvenile Atlantic salmon (Salmo salar L.). Gen. Comp. Endocrinol. 175, 92-99. doi:10.1016/j.ygcen.2011.10.001

Tschop, M., Smiley, D. L., and Heiman, M. L. (2000). Ghrelin induces adiposity in rodents. Nature 407, 908-913. doi:10.1038/35038090

Turano, M. J., Borski, R. J., and Daniels, H. V. (2007). Compensatory growth of pond-reared hybrid striped bass, Morone chrysops $\times$ Morone saxatilis, fingerlings. Proc. Natl. Acad. Sci. U.S.A. 38, 250-261.

Turano, M. J., Borski, R. J., and Daniels, H. V. (2008). Effects of cyclic feeding on compensatory growth of hybrid striped bass (Morone chrysops $\times M$. saxitilis) foodfish and water quality in production ponds. Aquac. Res. 39, 1514-1523. doi:10.1111/j.13652109.2008.02023.x

Turano, M. J. (2007). The Effects of Cyclic Feeding on Compensatory Growth and Water Quality in Hybrid Striped Bass, Morone chrysops $\times$ M. saxitilis. Ph.D. thesis, North Carolina State University, Raleigh.
Uchida, K., Kajimura, S., Riley, L. G., Hirano, T., Aida, K., and Grau, E. G. (2003). Effects of fasting on growth hormone/insulin-like growth factor I axis in the tilapia, Oreochromis mossambicus. Comp. Biochem. Physiol. A Mol. Integr. Physiol. 134, 429-439. doi:10.1016/S10956433(02)00318-5

Ueno, H., Yamaguchi, H., Kangawa, K., and Nakazato, M. (2005). Ghrelin: a gastric peptide that regulates food intake and energy homeostasis. Regul. Pept. 126, 11-19. doi:10.1016/j.regpep.2004.08.007

Unniappan, S., Canosa, L. F., and Peter, R. E. (2004). Orexigenic actions of ghrelin in goldfish: feeding-induced changes in brain and gut mRNA expression and serum levels, and responses to central and peripheral injections. Neuroendocrinology 79, 100-108. doi:10.1159/00007 6634

Unniappan, S., Lin, X., Cervini, L., Rivier, J., Kaiya, H., Kangawa, K., et al. (2002). Goldfish ghrelin: molecular characterization of the complementary deoxyribonucleic acid, partial gene structure and evidence for its stimulatory role in food intake. Endocrinology 143, 4143-4146. doi:10.1210/en.2002-220644

Unniappan, S., and Peter, R. E. (2004). In vitro and in vivo effects of ghrelin on luteinizing hormone and growth hormone release in goldfish. Am. J. Physiol. Regul. Integr. Comp. Physiol. 286, R1093-R1101. doi:10.1152/ajpregu.00669.2003

Unniappan, S., and Peter, R. E. (2005). Structure, distribution and physiological functions of ghrelin in fish. Comp. Biochem. Physiol. A Mol. Integr. Physiol. 140, 396-408. doi:10.1016/j.cbpb.2005.02.011

Very, N. M., Kittilson, J. D., Norbeck, L. A., and Sheridan, M. A. (2005). Isolation, characterization, and distribution of two cDNAs encoding for growth hormone receptor in rainbow trout (Oncorhynchus mykiss). Comp. Biochem. Physiol. B Biochem. Mol. Biol. 140, 615-628. doi:10.1016/j.cbpc.2004.12.008

Very, N. M., and Sheridan, M. A. (2002). The role of somatostatins in the regulation of growth in fish. Fish Physiol. Biochem. 27, 217-226. doi:10.1023/B:FISH.0000032727. 75493.e8

Volkoff, H., Bjorklund, J. M., and Peter, R. E. (1999). Stimulation of feeding behavior and food consumption in the goldfish, Carassius auratus, by orexin-A and orexin-B. Brain Res. 846, 204-209. doi:10.1016/S00068993(99)02052-1 
Volkoff, H., Canosa, L. F., Unniappan, S., Cerda-Reverter, J. M., Bernier, N. J., Kelly, S. P., et al. (2005). Neuropeptides and the control of food intake in fish. Gen. Comp. Endocrinol. 142, 3-19. doi:10.1016/j.ygcen.2004.11.001

Volkoff, H., Eykelbosh, A. J., and Peter, R. E. (2003). Role of leptin in the control of feeding of goldfish Carassius auratus: interactions with cholecystokinin, neuropeptide $\mathrm{Y}$ and orexin $\mathrm{A}$, and modulation by fasting. Brain Res. 972, 90-109. doi:10.1016/S00068993(03)02507-1

Volkoff, H., and Peter, R. E. (2001). Interactions between orexin A, NPY and galanin in the control of food intake of the goldfish, Carassius auratus. Regul. Pept. 101, 59-72. doi:10. 1016/S0167-0115(01)00261-0

Vonesh, J. R., and Bolker, B. M. (2005). Compensatory larval responses shift trade-offs associated with predatorinduced hatching plasticity. Ecology 86, 1580-1591. doi:10.1890/04-0535

Vong, Q. P., Chan, K. M., and Cheng, C. H. K. (2003). Quantification of common carp (Cyprinus carpio) IGF-I and IGF-II mRNA by real-time PCR: differential regulation of expression by GH. J. Endocrinol. 178, 513-521. doi:10.1677/joe.0.1780513

Wang, Y., Cui, Y., Yang, Y., and Cai, F. (2000). Compensatory growth in hybrid tilapia, Oreochromis mossambicus $\mathrm{x} O$. niloticus, reared in seawater. Aquaculture 189, 101-108. doi:10. 1016/S0044-8486(00)00353-7

Weatherley, A. H., and Gill, H. S. (1987). Growth increases produced by bovine growth hormone in grass pickerel, Esox americanus vermiculatus (Le Sueur), and the underlying dynamics of muscle fiber growth. Aquaculture 65, 55-66. doi:10.1016/0044-8486(87)90 270-5

Wieser, W., Krumschnabel, G., and Ojwang-Okwor, J. (1992). The energetics of starvation and growth after refeeding in juveniles of three cyprinid species. Environ. Biol. Fishes 33, 63-71. doi:10.1007/BF0000 2554

Wilson, P. N., and Osbourn, D. F. (1960). Compensatory growth after undernutrition in mammals and birds. Biol. Rev. 35, 324-361. doi:10.1111/j.1469185X.1960.tb01466.x

Won, E. T., Baltzegar, D. A., Picha, M. E., and Borski, R. J. (2012). Cloning and characterization of leptin in a Perciform fish, the striped bass (Morone saxatilis): Control of feeding and regulation by nutritional state. Gen Comp. Endocrinol. 178, 98-107. doi:10.1016/j.ygcen.2012.04.019

Wren, A. M., Small, C. J., Ward, H. L., Murphy, K. G., Dakin, C. L., Taheri, S., et al. (2000). The novel hypothalamic peptide ghrelin stimulates food intake and growth hormone secretion. Endocrinology 141 , 4325-4328. doi:10.1210/en.141.11. 4325

Zhang, H., Chen, H., Zhang, Y., Li, S., Lu, D., Zhang, H., et al. (2012). Molecular cloning, characterization and expression profiles of multiple leptin genes and a leptin receptor gene in orange-spotted grouper (Epinephelus coioides). Gen. Comp. Endocrinol. 181, 295-305. doi:10.1016/j.ygcen.2012.09.008

Zhang, Z.-H., and Felder, R. B. (2004). Melanocortin receptors mediate the excitatory effects of blood-borne murine leptin on hypothalamic paraventricular neurons in rat. Am. J. Physiol. Regul. Integr. Comp. Physiol. 286, R303-R310. doi:10.1152/ajpregu.00504.2003

Zhu, X., Wu, L., Cui, Y., Yang, Y., and Wootton, R. J. (2003).
Compensatory growth response in three-spined stickleback in relation to feed-deprivation protocols. J. Fish Biol. 62, 195-205. doi:10.1046/j.10958649.2003.00019.x

Conflict of Interest Statement: The authors declare that the research was conducted in the absence of any commercial or financial relationships that could be construed as a potential conflict of interest.

Received: 08 February 2013; accepted: 06 June 2013; published online: 01 July 2013. Citation: Won ET and Borski RJ (2013) Endocrine regulation of compensatory growth in fish. Front. Endocrinol. 4:74. doi: 10.3389/fendo.2013.00074

This article was submitted to Frontiers in Experimental Endocrinology, a specialty of Frontiers in Endocrinology.

Copyright $\odot 2013$ Won and Borski. This is an open-access article distributed under the terms of the Creative Commons Attribution License, which permits use, distribution and reproduction in other forums, provided the original authors and source are credited and subject to any copyright notices concerning any third-party graphics etc. 